\title{
Effects of Increased Precipitation and Grazing Management on Northeastern Montana Rangelands
}

\author{
FARREL A. BRANSON AND REUBEN F. MILLER
}

\section{Abstract:}

To determine possible vegetation changes, 15 plant communities on public lands in the Willow Creek basin near Glasgow, Montana, that were sampled in 1960 were resampled in 1977 . Most of the communities showed remarkable improvement in ground cover and forage production. Factors contributing to the changes included: (1) higher precipitation during the period between the first and second sampling than for the 10-year period prior to the first sampling, and (2) possibly, improved management practices, such as land treatments and application of rest-rotation grazing systems. These results are in conflict with the generally held view that western rangelands have deteriorated.

There are numerous publications that present evidence of range deterioration during the past 100 years. Most of these reports cite poor grazing practices, mainly heavy stocking, as the cause of undesirable vegetation changes (Martin 1975), although Hastings and Turner (1965) cite climatic change as a probable cause of shifts in vegetation zones in Arizona.

Some studies have shown that vegetation changes caused by drought alone (Albertson and Weaver 1944) may be more dra matic than changes attributed to grazing effects. For example, in the short grass type near Hays, Kansas (Albertson and Weaver 1942), plant cover in 1932 (pre-drought) was $89 \%$ for ungrazed, $85 \%$ for moderately grazed, and $80 \%$ for heavily grazed. In 1939 , after 6 years of drought, the cover was $22 \%$ for ungrazed, $27 \%$ for moderately grazed, and $18 \%$ for heavily grazed range. In southwest Kansas, some ranges had essentially no perennial grass cover at the end of the drought of the 1930's. The drought of 1952 to 1955 produced drastic reductions in plant cover (Albertson et al. 1957). Near Idalia in eastern Colorado on pre-drought range, the plant cover was $68.7 \%$, but in 1955 it was only $2.1 \%$ or a reduction of nearly $97 \%$. In the extensive literature on the vegetation changes on rangelands, we have not seen reports of reductions in plant cover caused by overgrazing by livestock that compare with these reported for effects of droughts in the central Great Plains.

Apparently, changes caused by grazing occur very slowly in salt-desert shrub and northern-desert shrub types. In western Colorado (Turner 1971), protection from grazing by sheep and cattle for 10 years caused essentially no change on ungrazed saltdesert shrub watersheds; however, small but highly significant decreases ( 1 to $9 \%$ ) in litter and moss, perennial plants, shrub crown cover, and ground cover (an increase of 12 hits per 100 observations on bare soil) were found on grazed watersheds. Both drought and grazing were considered causative factors for changes in western Colorado. In northern Utah (Rice and Westoby 1978), 15 years of protection against sheep, with or without protection against jackrabbits, had little effect on salt-desert vegetation. Under protection, halogeton (Halogeton glomeratus) generally decreased; peppergrass (Lepidium densiflorum) increased where present; winterfat (Ceratoides lanata) increased in cover but not in

\footnotetext{
Authors are botanist and hydrologist, U.S. Geological Survey, Water Resources Division, Federal Center, Denver, Colorado 80225.

Manuscript received May 28, 1979.
}

density where present. These changes seem insignificant when compared to those which have occurred in the Southwest, about which Martin (1975) states: "The vegetation on much southwestern semidesert range has shifted from grassland to brush since livestock ranching began back 100 years ago." It was also noted that, "The condition of many ranges has been depressed so long that no standard of potential is available." In an 18-year study in southern Arizona (Brown 1950), shrubs increased on all plots including those plots grazed by livestock, protected from livestock, and protected from livestock and rodents. It was concluded that, "The desert grassland is indicated by this study to be subclimax to desert shrub climax in southern Arizona." In southern New Mexico, grasslands have also been greatly reduced by the invasion of the undesirable shrubs (Branscomb 1958). On the Jornada Experimental Range near Las Cruces, New Mexico, grasslands decreased $28 \%$ between 1915 and 1946 and mesquite-dominated areas increased by $107 \%$. These changes were attributed to grazing, drought, and possibly a decrease in fires.

Shifts from grass- to shrub-dominated vegetation have been reported by several authors in Utah (Cottam 1947, Christensen and Johnson 1964, and Hull and Hull 1974). However, an analysis of early journals and diaries caused Vale (1975) to conclude that much of the Intermountain West has changed little over time. The area was dominated by shrubs, mainly big sagebrush (Artemisia tridentata) before the impact of settlers, and this holds today. This viewpoint is supported by the work of Passey and Hugie (1963). Although boundaries of the sagebrush type may have changed little, there is general agreement that marked changes have occurred within the type. Shrubs have increased, grasses and forbs have decreased, and voids created between shrubs have become filled by alien annuals (Young et al. 1976).

In contrast with much of the information contained in the above reports, several authors have proposed that range conditions have improved considerably over those present during the early days of uncontrolled livestock use (Cholis 1952, Renner 1954, and Strickler 1961). Renner (1954) states: "Since 1928, the livestock population of the 17 [western] states of the range area has increased 41 percent, from $32,807,000$ to $46,510,000$ animal units. Moreover, both improvement in the range and the increase in livestock have taken place in the face of substantial reduction in area devoted to range use." Much of this change was attributed to government technical and financial assistance to landowners. It was estimated that further improvement of 150 to $300 \%$ was possible on private and public range. Cholis (1952) found that between 1939 and 1950, the percent of ranges near Wilson Creek, Washington, in good and excellent condition increased from 5 to $32 \%$. At the end of 18 years of good management in the Wallowa Mountains of eastern Oregon (Strickler 1961), vegetation cover increased 30\%, forage production increased $174 \%$, and erosion was arrested.

In an analysis of the hydrologic effects of conservation structures in the Willow Creek basin in Montana, the area of the present study, for the years 1954 to 1968 Frickel (1972) found that peak 
discharge, runoff, and sediment yields were reduced by the treatments. The structures, mainly reservoirs and water spreaders, must also have caused improved livestock distribution and provided increased forage and both of these effects would be expected to cause improvement in range vegetation.

In 1960, some 15 plant communities and associated soils on public land in the Willow Creek drainage basin near Fort Peck, Montana were sampled (Branson et al. 1970). To determine possible vegetation changes, these plant communities were again sampled in 1977. Because several of the plant communities have widely distributed counterparts in the western United States, the results should have wide application. Analyses of soil moisture and soil chemistry factors affecting the plant communities are presented in the earlier report (Branson et al. 1970).

\section{Description of Area}

The study area is $24 \mathrm{~km}$ ( $15 \mathrm{mi}$ ) southwest of Glasgow, Montana, at an altitude of about $671 \mathrm{~m}(2,200 \mathrm{ft})$. The climate is continental semiarid, having cold winters and hot summers. Recorded temperatures have reached a low of $-51^{\circ} \mathrm{C}\left(-59^{\circ} \mathrm{F}\right)$ and a high of $47^{\circ} \mathrm{C}$ $\left(117^{\circ} \mathrm{F}\right)$. The 53-year average annual precipitation for several nearby weather stations is $315 \mathrm{~mm}$ (12.4 inches) (Weather Bureau 1924-1977).

Bearpaw shale of Late Cretaceous age is the principal parent material for soils of the area (Jensen and Varnes 1964). The shale, with a few thin beds of bentonite and limestone, is about $347.5 \mathrm{~m}$ $(1,140 \mathrm{ft})$ thick and is the source of parent materials for most of the upland and lowland soils of the area.

\section{Methods}

The all-contacts point quadrat method (Levy and Madden 1933) was used to measure vegetation. Upland plant communities were sampled by a continuous $329 \mathrm{~m}$ ( $1,080 \mathrm{ft})$ transect crossing seven plant communities. A frame containing 10 vertically oriented pins spaced $5 \mathrm{~cm}$ ( 2 inches) apart was placed alongside and parallel to a stretched tape, giving 6,480 pin projections for upland communities. The lowland communities were more widespread and were sampled by separate, systematically spaced $15.2-\mathrm{m}(50 \mathrm{ft})$ transects across each plant community. The sampling intensity for lowland plant communities was 600 pins for two communities having limited distribution (big sagebrush strip and greasewood [Sarcobatus vermiculatus] strip), and 1,200 pins for each of the more widespread communities (Nuttall saltbush [Atriplex nuttallii], blue grama [Bouteloua gracilis], wheatgrass [Agropyron smithii] meadow, greasewood, and silver sagebrush [Artemisia cana]). The number of pin projections used in this sampling is greater than the 100 points considered by Levy and Madden (1933) to be adequate for sampling dominants and the 400 or 500 points required for minor species. It was possible to duplicate closely transects of 1960 because most of the metal stakes used to mark transects and community boundaries were still in place in 1977. Pairs of data derived from comparative $10-\mathrm{ft}$ sections (60 pin projections) of transects for the two sampling dates were subjected to $t$-tests to determine significance of differences.

Precipitation records from Glasgow, Frazer, Fort Peck, Haxby, Jordan, Brusett, Malta, and Telegraph Creek were used to compute the mean values shown in Figure 1. These cities surround the study area and have weather records of 28 to 82 years through 1977. Although distances from the study area are 24 to $96 \mathrm{~km}$ (15 to $60 \mathrm{mi})$, altitudes are similar for all stations. Weather stations in a variety of directions were used to improve the probability of representing the different storm tracks that cross the study area.

Annual precipitation for the years 1951 through 1977 is shown in Figure 1. Average precipitation for the 10 years, 1951-1960, is about $36 \mathrm{~mm}$ (1.4 inches) below the 27 -year mean, which is nearly equal to the previously mentioned 53-year mean. The year of earlier vegetation sampling, 1960, had the lowest precipitation of any year shown. Precipitation for the 27 -year period varied from 180 to $439 \mathrm{~mm}$ (7.1 to $17.3 \mathrm{in}$ ). Averages for the years 1961-1970 and 1971-1977 were greater than the 27-year mean. Because pre-

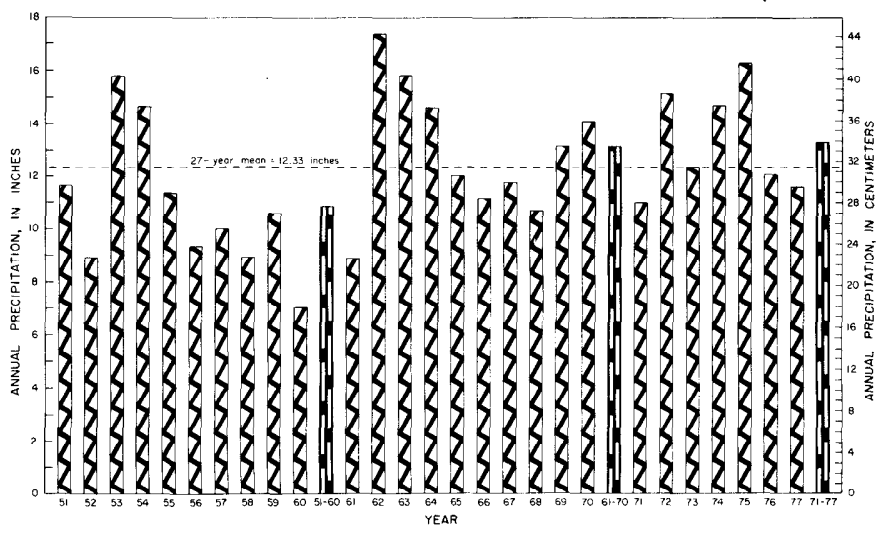

Fig. 1. Annual precipitation for the years 1951 through 1977 with mean values for three important periods.

cipitation for the 1951-1960 period was considerably below the long-term mean and precipitation for the 1961-1977 period was above the mean, we speculated that both quantitative and qualitative vegetation differences would be apparent in the data collected at the end of those two periods.

In addition to more favorable climate preceding the 1977 sampling, several treatment practices contributed to improvement of vegetation on the sampling sites. The construction of water spreaders and contour furrowing in the 1950 's, and additional furrows in the 1960's on the relatively barren Nuttall saltbush type in the pasture containing the seven upland sites (Archambeault pasture), greatly improved forage production on lowlands, which undoubtedly reduced grazing pressure on uplands. Contour furrows were also constructed in the other pasture in 1948-1949 (Branson et al. 1962).

\section{Results}

Available grazing records (provided by the Bureau of Land Management) for the two grazing allotments for the years 1953 through 1977 are shown in Figures 2 and 3. Grazing intensities were somewhat higher for post- than pre-1960 in the Lewis Reservoir Allotment (upland types sampled) and slightly lower for the Willow Creek Allotment (lowland types sampled). It does not appear that these changes in grazing intensities would explain the marked improvements in ground cover measured in most of the vegetation types. Vegetation improved during the 17 years even though grazing intensity more than doubled (an increase of 220\%) on the Lewis Reservoir Allotment (Fig. 2).

The Lewis Reservoir Allotment was divided into five pastures

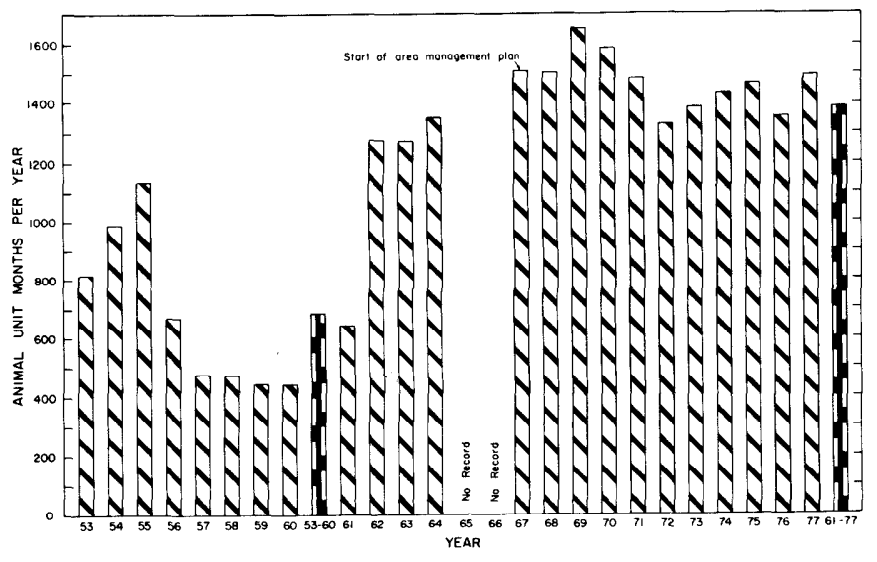

Fig. 2. Grazing intensities in animal unit months per year for the allotment (Lewis Reservoir Allotment) containing the upland types sampled. Mean values for two periods are shown. The allotment contains 15,621 acres $(6,322 \mathrm{ha})$. 


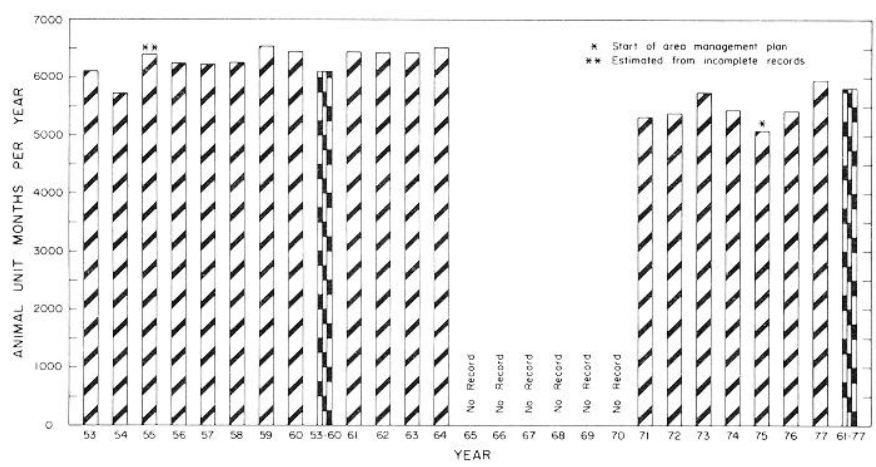

Fig. 3. Grazing intensities in animal unit months per year for the allotment (Willow Creek Allotment) containing the lowland types sampled. Mean values for each period are shown. There are 67,872 acres $(26,467 \mathrm{ha})$ in the allotment.

and a rest-rotation grazing system started in 1967. As a part of the grazing system, there was no grazing in 1971, 1972, 1976, and 1977 in the pasture where upland vegetation types were sampled. A similar three-pasture rest-rotation grazing system was started in 1975 in the Willow Creek Allotment; and the pasture where lowland vegetation types were sampled was not grazed in 1977 , the year of the second sampling. It does not seem probable that the grazing systems would account for the vegetation changes, especially not in the Willow Creek Allotment in which the first 3-year grazing cycle was completed in 1977.

For a general understanding of vegetation changes, the 15 sampling sites can be grouped into 8 plant communities that include 3 big sagebrush sites, 4 Nuttall saltbush sites, 2 greasewood sites, and single sampling sites for the remaining 5 plant communities (Fig. 4). Figure 4 shows, in summary form, the changes that occurred in vegetation and soil surface conditions during the 17 years between samplings. Shrubs increased greatly (the difference is significant at $p=>0.01$ ) in the silver sagebrush community (Figs. 4 and 5) but only slightly in other communities where shrubs were present in

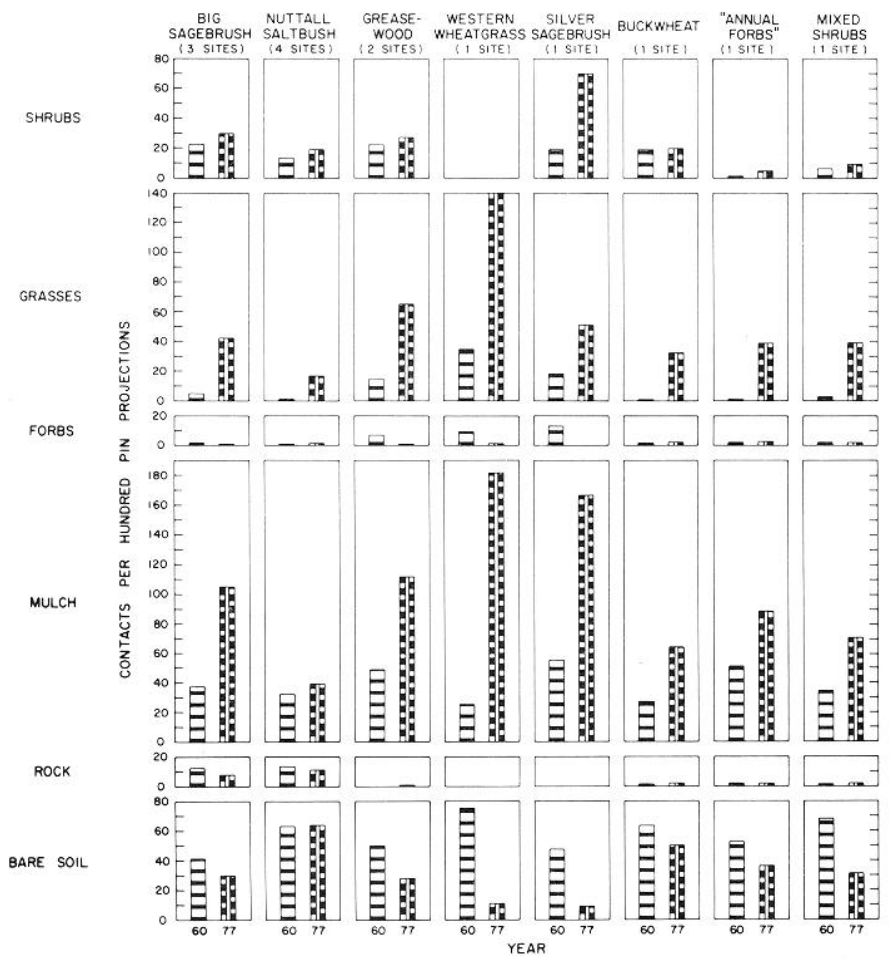

Fig. 4. Summary of changes in vegetation and soil-surface conditions between the sampling years of 1960 and 1977 for eight plant communities.
1960. Although the differences appears small in the big sagebrush type, the increase was significant $(p=>0.01)$. None of the other shrub increases were statistically different. The unusual increase in silver sagebrush is attributable to two factors: (1) silver sagebrush is more palatable than most shrubs in the area and, therefore, showed greater response to reduced grazing, and (2) the location of the community on level flood plain, adjacent to an intermittent stream readily accessable to livestock, caused previous heavy use. The site was grazed annually previous to the 1960 sampling.

Grasses and mulch showed consistent and large increases in all communities. Increases in grasses were highly significant $(p=$ $>0.01)$. Although the increase in grasses in the buckwheat community is almost infinite, the small number of replications (6 as compared to 60 in other communities) was not large enough to indicate statistical significance for the increase. Most remarkable was the increase in mulch in the wheatgrass meadow. There were increases in both standing and detached mulch in 1977. Either burial by sediment or removal by flowing water caused fewer contacts to be made on detached mulch in 1960, but neither of these factors seem to have removed mulch from the wheatgrass meadow in 1977. A detention dam downstream from the sampling site,

\section{A}
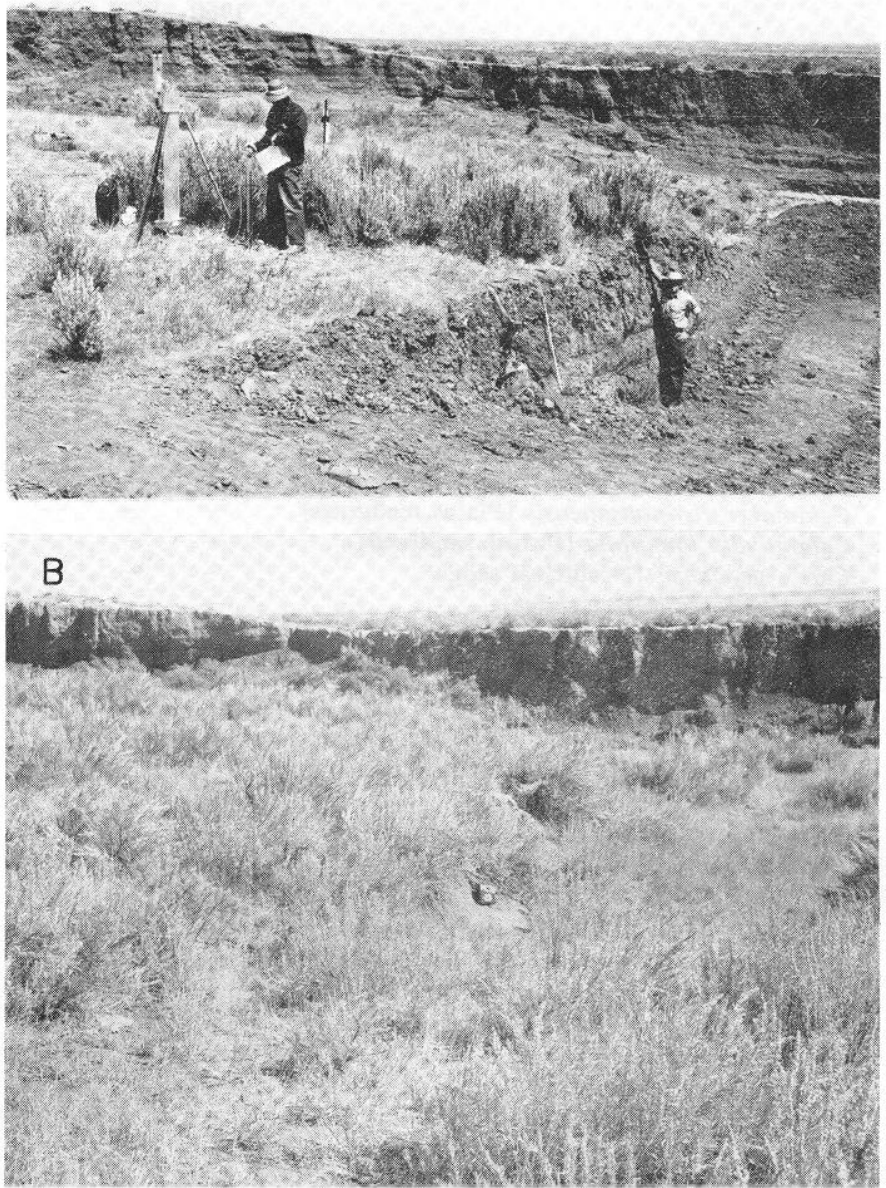

Fig. 5.

A. The silver sagebrush type as it appeared in 1960. The excavation to the right was made to facilitate soil sampling. A portable rainfallsimulating infiltrometer is in use in the left foreground.

B. Thickening of silver sagebrush during the 18-year period between photographs is quite apparent. The bottom of the excavation is occupied by grasses, mainly western wheatgrass. Camera failures in 1977, the year of vegetation sampling, necessitated rephotographing in 1978. 
actually a recently constructed raised roadway with a culvert through it, probably caused both increases in mulch and some of the increase in live vegetation in this community.

Rock remained much the same or decreased slightly between the two sampling periods. The decreases were undoubtedly related to increases in mulch and live plant cover.

Bare soil decreased considerably in most of the plant communities but remained about the same in the type dominated by Nuttall saltbush. Extremely fine-textured soil with high runoff and low soil-moisture storage (Branson et al. 1970) causes this desert shrub community with low production potential to be present in this semiarid climate. Similar insignificant changes were found even where protected from grazing for 10 years in western Colorado (Turner 1971); up to 15 years protection in Utah (Rice and Westoby 1978) caused little change in similar salt-desert shrub vegetation. Two of the four Nuttall saltbush sites sampled in 1960 were later contour-furrowed and required relocation of sampling areas by about $0.3 \mathrm{~km}(0.2 \mathrm{mi})$ in 1977 . These relocations introduce some uncertainty into the data but they are believed to be representative of 1977 conditions.
Quantitative changes between 1960 and 1977 by species for the 15 sites sampled are shown in Tables 1 and 2. Plant communities in the tables are arranged in the order sampled in the field from the top of a hill across upland communities (Table 1), then across lowland communities (Table 2). Most striking is the increase in grasses in the hilltop Nuttall saltbush community (Fig. 6), a type that was relatively barren in 1960 . This site, with a seasonal evapotranspiration of only $5 \mathrm{~cm}$ ( 2 inches) in 1960 (Branson et al. 1970), was the second driest of 15 sites sampled. It was surprising to find that species with relatively high moisture requirements, such as green needlegrass (Stipa viridula) and foxtail barley (Hordeum jubatum), were a prominent part of the vegetation in 1977 on a site where we probably would have predicted in 1960 that such species would never occupy. Mulch was $300 \%$ more plentiful in 1977 than in 1960.

Both big sagebrush and grasses increased greatly on the big sagebrush site but forbs had decreased in both kinds and amounts. Annuals, such as dooryard knotweed (Polygonum aviculare), , had decreased on most of the sites sampled. The abundance of annuals in 1960 was probably a response to drought conditions.

Table 1. Changes over 17 years in vegetation and soil-surface conditions on upland plant communities (contacts per 100 pins).

\begin{tabular}{|c|c|c|c|c|c|c|c|c|c|c|c|c|c|c|}
\hline & \multicolumn{2}{|c|}{$\begin{array}{c}\text { Nuttall } \\
\text { saltbush } \\
\text { (hilltop) }\end{array}$} & \multicolumn{2}{|c|}{$\begin{array}{l}\text { Big sagebrush } \\
\text { (below hilltop) }\end{array}$} & \multicolumn{2}{|c|}{$\begin{array}{c}\text { "Annual } \\
\text { forb" } \\
\text { type }\end{array}$} & \multicolumn{2}{|c|}{ Buckwheat } & \multicolumn{2}{|c|}{$\begin{array}{l}\text { Mixed } \\
\text { shrubs }\end{array}$} & \multicolumn{2}{|c|}{ Big sagebrush } & \multicolumn{2}{|c|}{$\begin{array}{l}\text { Nuttall } \\
\text { saltbush }\end{array}$} \\
\hline & 1960 & 1977 & 1960 & 1977 & 1960 & 1977 & 1960 & 1977 & 1960 & 1977 & 1960 & 1977 & 1960 & 1977 \\
\hline \multicolumn{15}{|l|}{ Shrubs } \\
\hline Artemisia cana Silver sagebrush) & - & 3.2 & - & - & - & - & - & - & - & - & - & - & - & - \\
\hline Artemisia frigida (Fringed sagewort) & - & 0.4 & - & - & - & - & - & - & - & - & - & - & - & - \\
\hline Artemisia tridentata (Big sagebrush) & 0.3 & 6.4 & 15.1 & 30.7 & - & - & - & - & 3.2 & 1.7 & 12.6 & 39.3 & - & - \\
\hline Atriplex nuttallii (Nuttall saltbush) & 1.0 & 10.6 & - & - & - & - & - & - & - & - & 0.3 & 0.3 & 15.3 & 21.2 \\
\hline Chrysothamnus nauseosus (Rubber rabbitbrush) & - & - & - & - & 0.2 & 4.5 & 2.2 & - & - & 1.9 & 1.0 & - & - & - \\
\hline Chrysothamnus sp. (Rabbitbrush) & - & - & - & - & - & - & - & - & - & - & 0.2 & - & - & - \\
\hline Eriogonum multiceps (Buckwheat) & - & - & - & - & 0.1 & - & 17.2 & 15.0 & - & 2.2 & 0.3 & - & - & - \\
\hline Opuntia polycantha (Plains pricklypear) & 1.5 & 1.8 & 2.3 & 1.0 & - & - & - & - & - & 0.2 & 0.2 & 0.3 & 0.3 & 0.8 \\
\hline Rosa arkansana (Rose) & - & - & - & - & - & - & - & 4.8 & 3.1 & 2.7 & - & - & - & - \\
\hline Sarcobatus vermiculatus (Greasewood) & - & - & - & - & - & - & - & - & - & - & 0.9 & 0.8 & - & - \\
\hline \multicolumn{15}{|l|}{ Grasses and grasslike } \\
\hline Agropyron smithii (Wester & 0.1 & 16.4 & 2.4 & 30.3 & 0.2 & 35.9 & 0.2 & 32.5 & 0.5 & 27.6 & 0.9 & 25.1 & - & 8.3 \\
\hline Agropyron trachycanlum (Slender wheatgrass) & - & - & - & - & - & - & - & - & - & - & - & - & - & 2.5 \\
\hline Calamagrostis montanensis (Plains reedgrass) & - & - & - & - & - & - & - & - & 1.4 & - & - & - & - & - \\
\hline Calamovilfa longifolia (Prairie sandreed) & - & - & - & - & - & - & - & - & 0.8 & 6.5 & - & - & - & - \\
\hline Carex eleocharis (Needleleaf sedge) & - & - & - & - & - & - & - & - & - & 4.0 & - & - & - & - \\
\hline Carex heliophila (Sun sedge) & - & - & 0.4 & - & - & - & - & - & 0.1 & 1.5 & - & - & - & - \\
\hline Hordeum jubatum (Foxtail barley) & - & 5.6 & - & - & - & 3.4 & - & - & - & - & 0.1 & - & - & 5.8 \\
\hline Poa secunda (Sandberg bluegrass) & - & 0.6 & - & - & - & - & - & - & - & - & - & 2.8 & 0.5 & 16.7 \\
\hline Stipa viridula (Green needlegrass) & - & 8.4 & - & 3.0 & - & - & - & - & - & - & - & - & - & 0.8 \\
\hline \multicolumn{15}{|l|}{ Forbs } \\
\hline Artemisia longifolia & - & - & - & - & - & - & - & 2.2 & - & 1.3 & - & - & - & - \\
\hline Aster canescens (Hoary aster) & 0.1 & - & 1.0 & - & - & - & - & - & - & $-\ldots$ & - & - & - & - \\
\hline Atriplex argentea (Tumbling saltbush) & 0.2 & - & - & - & - & - & - & - & - & - & - & - & - & - \\
\hline Comandra umbellata (Toadflax) & 一 & - & - & - & - & - & 0.2 & - & - & - & - & - & - & - \\
\hline Grindelia squarrosa (Gumweed) & - & - & 0.1 & - & 0.1 & 2.6 & - & - & - & 0.2 & 0.1 & - & - & 0.4 \\
\hline Lappula echinata (European stickseed) & - & - & - & - & - & 0.1 & - & - & - & - & - & - & - & - \\
\hline Lepidium densiflorum (Prairie pepperweed) & - & - & 0.1 & - & - & - & - & - & - & - & - & - & - & - \\
\hline Liatris punctata (Dotted gayfeather) & - & - & - & - & - & - & - & - & 0.3 & - & - & - & - & - \\
\hline Lomatium macrocarpa (Bigseed lomatium) & - & - & 0.4 & - & - & - & - & - & - & - & - & - & - & - \\
\hline Lygodesmia juncea Skeltonweed) & - & - & - & - & - & - & - & - & 0.2 & - & - & - & - & - \\
\hline sp. (Penstemon) & - & - & - & - & - & - & - & - & 0.2 & - & - & - & - & - \\
\hline Polygonum aviculare (Dooryard knotweed) & - & - & 2.4 & - & 2.1 & - & 1.2 & - & 0.7 & - & 1.1 & 0.6 & - & 5.4 \\
\hline Solidago missouriensis (Missouri goldenrod) & - & - & - & - & - & - & - & - & - & 0.2 & - & - & - & - \\
\hline Sphaeralcea coccinea (Scarlet globemallow) & - & - & 0.4 & - & - & - & - & - & - & - & - & - & - & - \\
\hline Thermopsis rhombifolia (Goldenpea) & - & - & - & - & - & - & - & - & 1.1 & 0.2 & 0.1 & - & - & - \\
\hline Unidentified forbs & - & - & - & - & - & - & - & - & 0.1 & - & - & - & - & - \\
\hline Mulch & 18.6 & 56.2 & 45.7 & 93.0 & 50.4 & 88.8 & 26.8 & 63.2 & 33.9 & 78.4 & 48.0 & 103.3 & 37.6 & 41.7 \\
\hline Bare soil & 33.8 & 15.0 & 21.9 & 15.3 & 52.2 & 36.4 & 63.0 & 49.8 & 68.1 & 31.0 & 48.2 & 41.0 & 65.8 & 79.2 \\
\hline Rock & 54.4 & 44.0 & 37.4 & 24.3 & 1.7 & 1.6 & 0.8 & 1.8 & 0.7 & 1.2 & 0.3 & - & - & - \\
\hline Hundreds of pins & 12 & 6 & 7 & 3 & 9 & 7 & 3.8 & 4 & 12 & 19 & 17.4 & 10.4 & 3.8 & 2.4 \\
\hline
\end{tabular}


The most enigmatic and dynamic of the 15 sites was the one designated the "annual forb type" in 1960. When observed in 1957 , the site was occupied by the relatively mesic foxtail barely ( $80 \%$ of the plant cover) (Fig. 7); but 3 years later (1960) no foxtail was present and the most prominent plant was an annual, dooryard knotweed. After 3 moist years, the site was again occupied by foxtail barley in 1964, and by 1977 the dominant species was the long-lived perennial, western wheatgrass. Factors contributing to the dynamic nature of this habitat were listed by Branson et al. (1970) as follows:

1) Surface of the site is concave and it occupies a position on the hill below two convex surfaces indicating that it must receive run-in moisture from upslope.

2) The deep wetting shown in this clayey soil causes the soil to crack and dry deeply in dry years.

3) Lateral movement of moisture into the site is indicated by the large quantity of moisture at depth in the soil in May, but this probably occurs only during moist years.

The present desirable perennial grass vegetation on the site must also be a response primarily to above average precipitation for most years during the 1961-1977 period (Fig. 1) and secondarily to land treatment practices. It is interesting to speculate about possi-

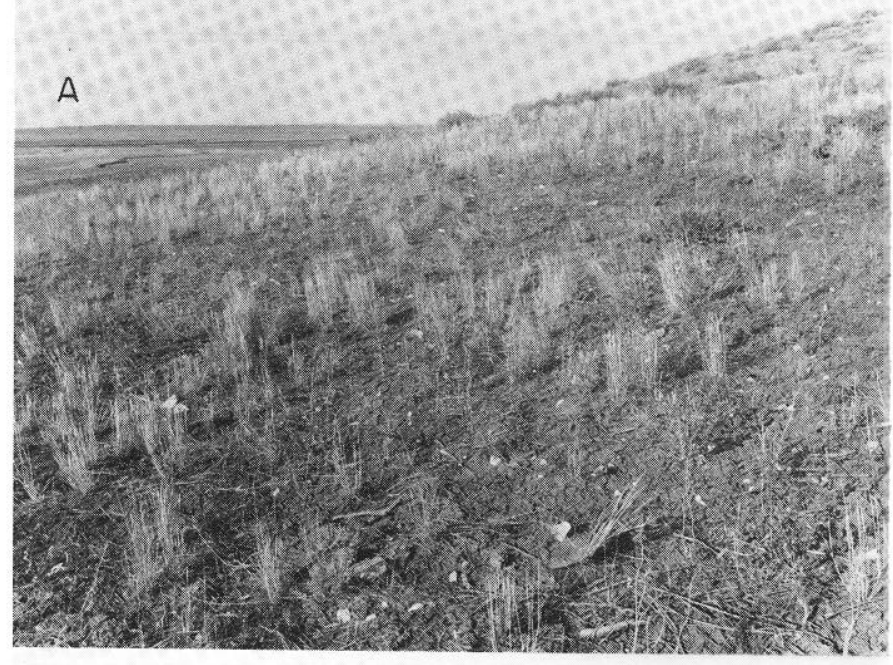

A
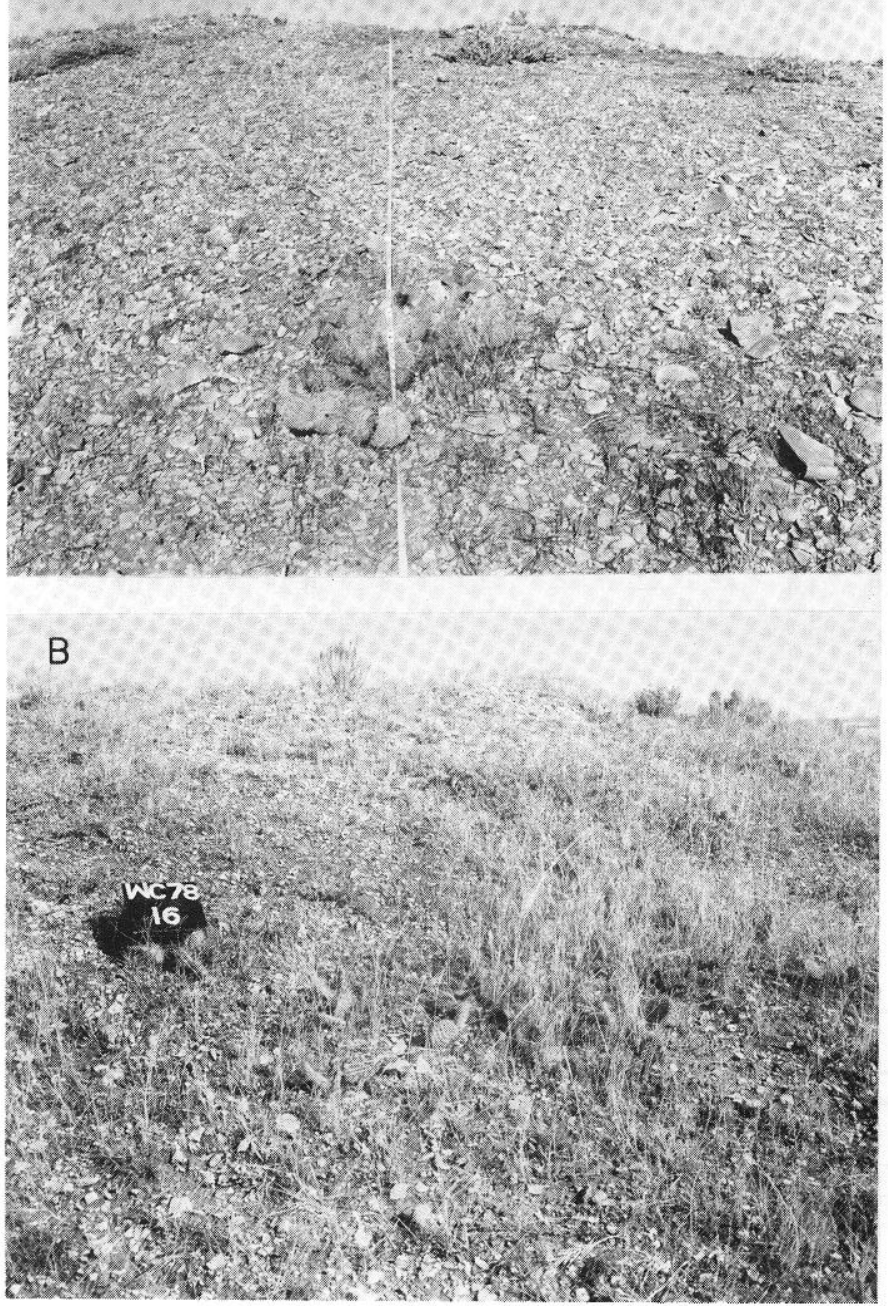

\section{Fig. 6.}

A. The hilltop Nuttall saltbush type as it appeared in 1960. Plains pricklypear is seen in the foreground, Nuttall saltbush near the top of the hill, and there is no grass visible.

B. In 1978 there is an abundance of western wheatgrass. Nuttall saltbush and pricklypear are present but less conspicuous. Big sagebrush has become established at the top of the hill.

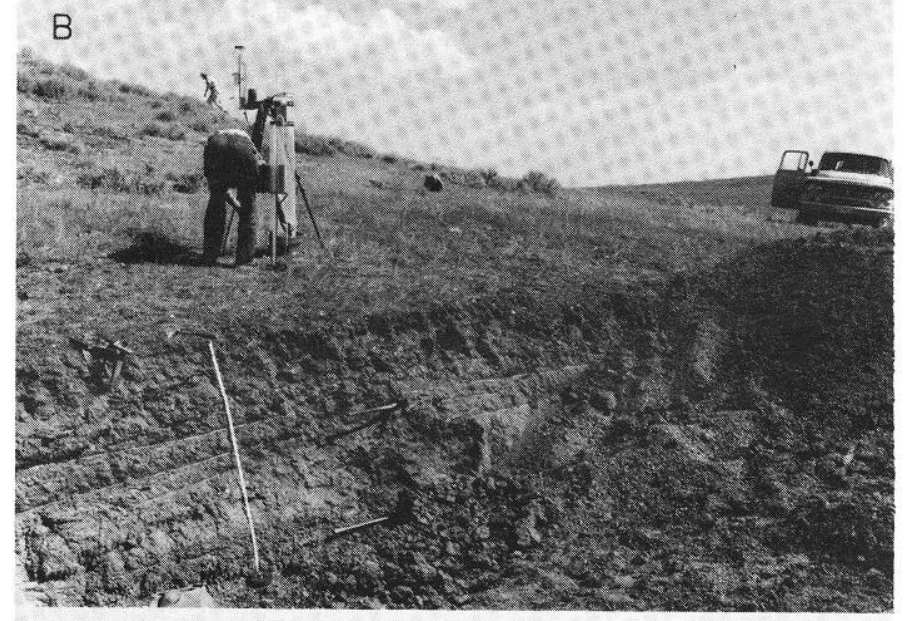

C

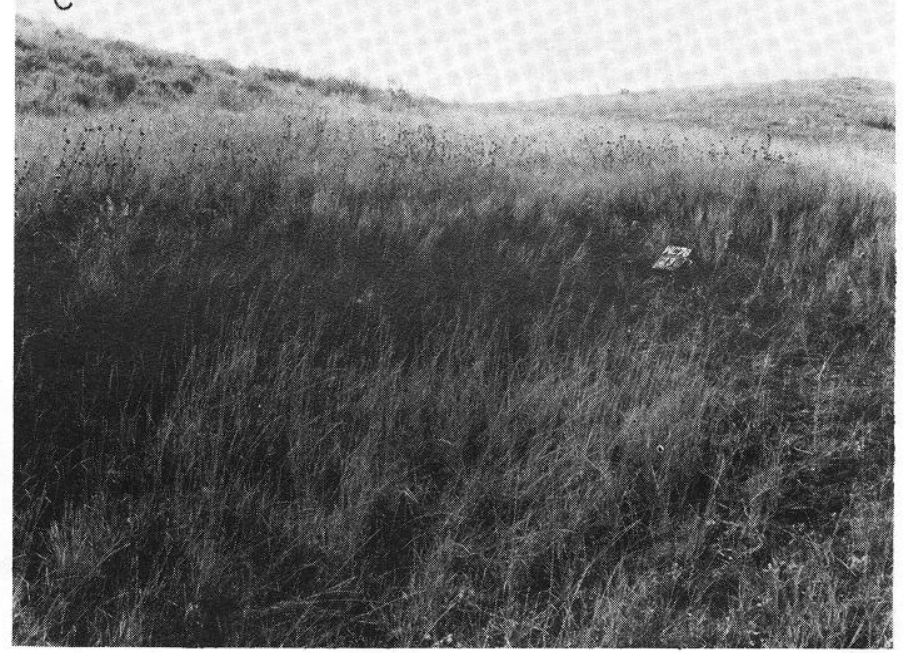

Fig. 7.

A. The "annual forb" type as it appeared in 1957 showing a stand of foxtail.

B. In 1960, following 3 dry years (Fig. 1), annual forbs had replaced foxtail.

C. In 1978, following a series of years with above average precipitation, a nearly pure stand of western wheatgrass occupied the site, including the soil pit that was excavated in 1960. 
Table 2. Changes over 17 years in vegetation and soil-surface conditions for lowland plant communities (contacts per 100 pins).

\begin{tabular}{|c|c|c|c|c|c|c|c|c|c|c|c|c|c|c|c|c|}
\hline & \multicolumn{2}{|c|}{$\begin{array}{c}\text { Nuttall } \\
\text { saltbush } \\
\text { slick }\end{array}$} & \multicolumn{2}{|c|}{$\begin{array}{r}\text { Nuttall } \\
\text { saltbush } \\
\text { semislick }\end{array}$} & \multicolumn{2}{|c|}{$\begin{array}{c}\text { Blue } \\
\text { grama }\end{array}$} & \multicolumn{2}{|c|}{$\begin{array}{l}\text { Sagebrush } \\
\text { strip }\end{array}$} & \multicolumn{2}{|c|}{$\begin{array}{l}\text { Greasewood } \\
\text { strip }\end{array}$} & \multicolumn{2}{|c|}{$\begin{array}{c}\text { Western } \\
\text { Wheatgrass }\end{array}$} & \multicolumn{2}{|c|}{ Greasewood } & \multicolumn{2}{|c|}{$\begin{array}{c}\begin{array}{c}\text { Silver } \\
\text { sagebrush }\end{array} \\
\end{array}$} \\
\hline & 1960 & 1977 & 1960 & 1977 & 1960 & 1977 & 1960 & 1977 & 1960 & 1977 & 1960 & 1977 & 1960 & 1977 & 1960 & 1977 \\
\hline \multicolumn{17}{|l|}{ Shrubs } \\
\hline $\begin{array}{l}\text { Artemisia cana (Silver } \\
\text { sagebrush) } \\
\text { Artemisia frigida (Fringed }\end{array}$ & - & - & - & - & - & - & - & - & - & - & - & - & 1.2 & 0.2 & 15.0 & 69.0 \\
\hline sagewort) & - & - & - & - & - & 1.8 & - & 0.4 & - & - & - & - & - & - & - & \\
\hline $\begin{array}{l}\text { Artemisia tridentata (Big } \\
\text { sagebrush) } \\
\text { Atriplex nuttallii (Nuttall }\end{array}$ & - & - & - & - & 4.7 & 12.9 & 31.9 & 36.6 & - & - & - & - & - & 2.6 & - & - \\
\hline & 8.2 & 12.5 & 17.3 & 11.3 & 0.5 & 1.8 & 2.0 & 9.4 & 8.8 & 14.0 & - & - & - & 1.2 & - & - \\
\hline Rubber rabb & - & - & - & - & - & - & - & - & - & - & - & - & - & - & 1.9 & - \\
\hline cantha (Plains & 2.4 & 0.6 & 7.2 & 6.4 & 1.8 & 1.2 & - & 0.4 & - & - & - & - & - & 0.2 & - & - \\
\hline $\begin{array}{l}\text { Rosa arkansana (Rose) } \\
\text { Sarcobatus vermiculatus }\end{array}$ & - & - & - & - & - & - & - & - & - & - & - & - & - & - & 1.5 & - \\
\hline (Greasewooc & - & - & - & - & - & - & - & - & 11.8 & 20.0 & - & - & 21.8 & 16.7 & - & 0.6 \\
\hline $\begin{array}{r}\text { Grasses ar } \\
\text { Agropyl } \\
\text { wheat: }\end{array}$ & - & 0.1 & - & 0.2 & 6.8 & 17.8 & 7.3 & 21.4 & 4.2 & 34.0 & 32.9 & 137.0 & 75.6 & 15.8 & 49.7 & \\
\hline $\begin{array}{l}\text { Agropyron trachycaulum } \\
\text { (Slender wheatgrass) } \\
\text { Bouteloua gracilis (Blue }\end{array}$ & - & - & - & - & - & - & - & - & - & - & - & 1.2 & - & - & 2.4 & - \\
\hline $\begin{array}{l}\text { Bouteloua gracilis (Blue } \\
\text { grama) } \\
\text { Carex eleocharis (Needle- }\end{array}$ & - & - & - & - & 8.8 & 33.8 & 0.7 & 0.6 & - & - & - & - & - & - & - & - \\
\hline & - & - & - & - & 0.2 & - & - & - & - & - & - & - & - & - & - & - \\
\hline $\begin{array}{l}\text { Carex heleophilia (Sun sedge) } \\
\text { Hordeum jubatum (Foxtail }\end{array}$ & - & - & - & - & 0.4 & - & - & - & - & - & - & - & - & - & - & - \\
\hline $\begin{array}{l}\text { barley) } \\
\text { Poa secunda (Sandberg }\end{array}$ & - & - & - & - & - & - & - & 0.6 & - & - & 1.7 & 1.8 & - & - & 0.1 & 1.0 \\
\hline paniculatus & - & - & 1.1 & 3.5 & 1.2 & 7.7 & 0.4 & 11.7 & 2.3 & 10.3 & - & - & 0.5 & 9.2 & - & 1.0 \\
\hline $\begin{array}{l}\text { (Tumblegrass) } \\
\text { Sitanion hystrix (Bottle- }\end{array}$ & - & 0.5 & - & - & - & 1.0 & - & 0.6 & - & 0.2 & - & - & - & - & - & - \\
\hline $\begin{array}{l}\text { brush squirreltail) } \\
\text { Stipa comata (Needle-and- }\end{array}$ & - & - & - & 0.2 & - & 0.2 & - & - & - & - & - & - & - & - & - & - \\
\hline $\begin{array}{l}\text { thread) } \\
\text { Stipa vir }\end{array}$ & $\ldots$ & - & - & - & - & 0.2 & 0.7 & - & - & - & - & - & - & - & - & - \\
\hline needle & - & - & - & - & - & - & 1.0 & 1.4 & - & - & - & - & - & 0.2 & - & 0.2 \\
\hline
\end{tabular}

Forbs and cryptogams

Allium textile (Textile onion)

Aster canescens (Hoary aster)

Chenopodium album

(Lambsquarters)

Lappula echinata (European stickseed)

Lepidium densiflorum

(Prairie pepperweed)

Melilotus officinale (Yellow sweetclover)

Monolepis nuttalliana

(Nuttall monolepis)

Plantage elongata (Plan-

tain)

Phlox hoodii (Hoods phlox)

Polygonum aviculare (Dooryard knotweed)

Rumex sp. (Dock)

Selaginella densa (Clubmoss)

Sphaeraicea coccinea (Scar-

let globemallow)

Tragopogon pratense (Oyster salsify)

Vicia americana (American vetch)

Xanthium commune

(Cocklebur)

Unidentified forbs 


\begin{tabular}{|c|c|c|c|c|c|c|c|c|c|c|c|c|c|c|c|c|}
\hline & \multicolumn{2}{|c|}{$\begin{array}{c}\text { Nuttall } \\
\text { saltbush } \\
\text { slick }\end{array}$} & \multicolumn{2}{|c|}{$\begin{array}{c}\text { Nuttall } \\
\text { saltbush } \\
\text { semislick }\end{array}$} & \multicolumn{2}{|c|}{$\begin{array}{c}\text { Blue } \\
\text { grama }\end{array}$} & \multicolumn{2}{|c|}{$\begin{array}{c}\text { Sagebrush } \\
\text { strip }\end{array}$} & \multicolumn{2}{|c|}{$\begin{array}{c}\text { Greasewood } \\
\text { strip } \\
\end{array}$} & \multicolumn{2}{|c|}{$\begin{array}{c}\text { Western } \\
\text { wheatgrass }\end{array}$} & \multicolumn{2}{|c|}{ Greasewood } & \multicolumn{2}{|c|}{$\begin{array}{c}\text { Silver } \\
\text { sagebrush }\end{array}$} \\
\hline & 1960 & 1977 & 1960 & 1977 & 1960 & 1977 & 1960 & 1977 & 1960 & 1977 & 1960 & 1977 & 1960 & 1977 & 1960 & 1977 \\
\hline Mulch & 13.2 & 3.2 & 44.1 & 17.9 & 60.9 & 91.5 & 42.4 & 119.4 & 41.5 & 82.2 & 24.5 & 181.5 & 55.8 & 141.8 & 55.1 & 166.4 \\
\hline Bare soil & 87.3 & 93.0 & 65.0 & 69.5 & 21.6 & 23.4 & 52.9 & 33.4 & 60.2 & 37.3 & 74.8 & 10.6 & 40.1 & 20.8 & 47.7 & 9.3 \\
\hline Rock & - & - & - & - & 10.8 & 9.3 & - & - & - & 0.3 & - & - & - & - & - & - \\
\hline Pin projections per type & 1200 & 1200 & 1200 & 1200 & 1200 & 700 & 700 & 600 & 600 & 1200 & 1200 & 1200 & 1200 & 1200 & 1200 & 1200 \\
\hline
\end{tabular}

ble changes in the type if another series of dry years were to occur Would the present management practices result in survival of the western wheatgrass? We can only guess that they might if the drought was not severe and prolonged.

Contacts on shrubs in the mixed shrub type changed very little, but grasses, especially western wheatgrass, increased greatly. However, shrubs did increase in both the big sagebrush type near the top of the hill and Nuttall saltbush type at the bottom of the hill. In these two types, as in all the other types, there were marked increases in contacts on grasses.

The two lowland Nuttall saltbush types (Table 2) showed little change between the two sampling dates. Lack of response by this type to increases in precipitation and improved grazing management indicates that only by drastic treatments, such as contour furrowing (Branson et al. 1962, Branson et al. 1966, and Wight et al. 1978), can improvement be effective within a reasonable period of time.

In the blue grama type, contacts on shrubs more than doubled $(233 \%)$ and grasses more than tripled $(349 \%)$. More years of data would be required to determine whether or not increased grass vigor would eventually cause a decline in shrubs. Forbs were relatively unimportant on both sampling dates.

In both the sagebrush strip and the greasewood strip, contacts on shrubs showed little change, but grasses increased $359 \%$ and $685 \%$, respectively. In both types there was considerable increase in the palatable. Nuttall saltbush. Forbs decreased in both types.

A fourfold increase in contacts on grasses occurred in the western wheatgrass meadow. Forbs, especially the annual dooryard knotweed, decreased. The most remarkable change was the increase in mulch $(740 \%)$.

One of the few types to show a decrease in the dominant plant was greasewood. In this type also, there was an increase in grass and a decrease in forbs.

The increase in silver sagebrush is discussed above. Here, too, forbs, almost all annuals, decreased and grasses and mulch increased.

The most probable cause of most of the impressive range improvement in the Willow Creek watershed must be the greater precipitation during the 17 years between the years 1961 and 1977 as compared to the 1951 to 1960 period. During this latter period, average annual precipitation was $22 \%$ (60 mm or 2.4 in) greater than for the former period. This conclusion is in agreement with that of White et al. (1978) who, for time intervals similar to those of our study, found similar improvement in vegetation on public lands in southeastern Montana and attributed the changes primarily to greater precipitation in years following drought.

Grazing intensities for the two periods are probably not causative because they were equal on one pasture and somewhat greater on the other for the post-1960 period. Most of the land treatments, such as reservoir construction and contour furrows, were present before 1960 and thus not a major probable cause of improvement. Rest-rotation grazing had been in effect for only 3 years on one pasture and, although applied for 11 years on the other pasture, is not a probable cause of improvement. Improvement of the magnitude found in the pasture with 3 years of rest-rotation grazing would probably not have occurred with 3 years of complete rest and, therefore, must be attributed primarily to increased precipitation between 1960 and 1977 . These results suggest that caution should be exercised in attributing vegetation improvement entirely to management practices. Such evaluations should include carefully planned control comparison areas and analyses of climatic changes.

\section{Discussion and Conclusions}

There is a widely held opinion that western rangelands, especailly those administered by the Department of the Interior, Bureau of Land Management, are and have been deteriorating for years. This view is strongly stated in a "Report to the Congress" by the Comptroller General of the United States (1977):

The Nation's public rangelands have been deteriorating for years and, for the most part, are not improving. Deterioration can be attributed principally to poorly managed livestock grazing.

Several environmental groups in the mid-1970's decided that the Bureau of Land Management was not satisfactorily managing public rangelands and they initiated legal action against the agency. As a result of this action, "Development and implementation of land management plans for these [public domain] lands cannot be completed until 1988 because of the April 1975 courtordered agreement requiring the preparation of environmental impact statements" (Comptroller General 1977).

A disturbing fact is that little, if any, quantitative data on vegetation changes, towards improvement or deterioration, is available for public domain lands. This means that many important decisions have been and will be made on the basis of opinion because of the lack of sound data. It is hoped that this report will alleviate this deficiency partially, but it leaves many questions unanswered. It is apparent that most of the vegetation types improved greatly during the 17 years between sampling dates, but was the range in a deteriorated state in 1960 ? Have the vegetation types that improved now reached their potential productivity? With the information available now, these questions cannot be answered with a high degree of certainty. At least, there can be no doubt about the fact that herbage production and range condition on the area studied have greatly improved. There is reason to suspect that this has happened on many other rangeland areas, both those privately owned and those managed by the Bureau of Land Management as is indicated in a recent report. Also, the Department of Interior, Bureau of Land Management (1975), indicates that more intensive livestock-management programs have resulted, and could in the future result, in range improvement. The report contains the following statements:

The increase in the percentage of national resource lands in the improving trend category can be attributed to the Bureau's intensive livestock management program (AMP's). Studies on allotments covered by properly supervised AMP's generally indicate that intensive livestock management has all but halted the declining trend in range condition. Trend studies conducted on 6.6 million acres (approximately 25 percent) of the NRL's [National Resource Lands] covered by AMP's show the trend is improving on 3.6 million acres (approxi- 
mately 54 percent), indefinite or static on 2.8 million acres (approximately 42 percent), and declining on only 225,000 acres (approximately 4 percent).

\section{Literature Cited}

Albertson, F.W., G.W. Tomanek, and Andrew Riegel. 1957. Ecology of drought cycles and grazing intensity on grasslands of the central Great Plains. Ecol. Monog. 27:27-44.

Albertson, F.W., and J.E. Weaver. 1942. History of native vegetation of western Kansas during seven years of continuous drought. Ecol. Monog. 12:23-51.

Albertson, F.W., and J.E. Weaver. 1944. Effects of drought, dust, and intensity of grazing on cover and yield of short-grass pastures. Ecol. Monog. 14:1-29.

Branscomb, B.L. 1958. Shrub invasion of a southern New Mexico desert grassland range. J. Range Manage. 11:129-133.

Branson, F.A., R.F. Miller, and I.S. McQueen. 1962. Effects of contour furrowing, grazing intensities, and soils on infiltration rates, soil moisture, and vegetation near Fort Peck, Montana. J. Range Manage. 15:151-158.

Branson, F.A., R.F. Miller, and I.S. McQueen. 1966. Contour furrowing, pitting, and ripping on rangelands of the western United States. J. Range Manage. 19:182-190.

Branson, F.A., R.F. Miller, and I.S. McQueen. 1970. Plant communities and associated soil and water factors on shale-derived soils in northeastern Montana. Ecology 51:311-319.

Brown, A.L. 1950. Shrub invasion of southern Arizona grassland. J. Range Manage. 3:172-177.

Cholis, G.J. 1952. Range condition in Washington fifty years ago and now. J. Range Manage. 5: 129-134.

Christensen, E.M., and H.B. Johnson. 1964. Presettlement vegetation and vegetational change in three valleys in central Utah. Brigham Young University, Sci. Bull., Biol. Serv., v. 4, no. 4, 16 p.

General Accounting Office. 1977. Public lands continue to deteriorate. Comptroller General of the United States, Report to the Congress, CED-77-88. $28 \mathrm{p}$.

Cottam, W.P. 1947. Is Utah Sahara bound? Bull. Univ. Utah 37:1-40.

Frickel, D.G. 1972. Hydrology and effects of conservation structures, Willow Creek Basin, Valley County Montana, 1954-68. U.S. Geol. Survey, Water-Supply Pap. 1532-G. 34 p.
Hastings, J.R., and R.M. Turner. 1965. The changing mile. Univ. Arizona Press, Tucson. $317 \mathrm{p}$.

Hull, A.C. Jr., and M.K. Hull. 1974. Presettlement vegetation of Cashe Valley, Utah and Idaho. J. Range Manage. 27:27-29.

Jensen, F.S., and H.D. Varnes. 1964. Geology of the Fort Peck area, Garfield, McCone and Valley Counties, Montana. U.S. Geol. Survey Prof. Pap. 414F. 49 p.

Levy, E.B., and E.A. Madden. 1933. The point method of pasture analysis. New Zealand J. Agr. 46:267-279.

Martin, S.C. 1975. Ecology and management of southwestern semi-desert grass-shrub ranges: The status of our knowledge. U.S. Dep. Agr., Forest Serv. Res. Pap. RM-156. 39 p.

Passey, H.B., and V.K. Hugie. 1963. Some plant-soil relationships on an ungrazed area in southeastern Idaho. J. Range Manage. 16: 113-118.

Renner, F.G. 1954. The future of our range resources. J. Range Manage. 7:55-56.

Rice, Barbara, and Mark Westoby. 1978. Vegetative responses of some Great Basin shrub communities protected against jackrabbits and domestic stock. J. Range Manage. 31:28-34.

Strickler, G.S. 1961. Vegetation and soil condition changes on subalpine grasslands in eastern Oregon. U.S. Dep. Agr., Forest Serv., Pacific Northwest Forest and Range Exp. Sta. Res. Pap. 40, 46 p.

Turner, G.T. 1961. Soil and grazing influences on a salt-desert shrub range in western Colorado. J. Range Manage. 24:31-37.

U.S. Department of the Interior, Bureau of Land Management. 1975. Range condition report prepared for the Senate Committee on Appropriations. U.S. Government Printing Office, Washington, D.C. 126 p.

Vale, T.R. 1975. Presettlement vegetation in the sagebrush-grass area of the Intermountain West. J. Range Manage. 28:32-36.

Weather Bueau. 1925-1977. U.S. Department of Commerce. Climatological Data, Annual Summary. Vol. 31-83.

White, L.M., J.J. Newbauer III, and J.R. Wight. 1978. Vegetation differences on native range during 38 years in eastern Montana. In: Proc. First Inernat. Rangeland Cong., D.N. Hyder (ed), Soc. for Range Manage., Denver. p. 260-262.

Wight, J.R., E.L. Neff, and R.L. Soiseth. 1978. Vegetation response to contour furrowing. J. Range Manage. 31:97-101.

Young, J.A., R.A. Evans, and P.T. Tueller. 1976. Great Basin plant communities-pristine and grazed. In: Robert Elston (ed), Holocene environmental change in the Great Basin. Nevada Archeological Survey Res. Pap. No. 5, p. 186-216.

\section{SRM Election Results}

The Elections Committee composed of William Laycock (Chairman), Herbert Fisser, Wallace Gallaher, Allan Strobel, and Floyd Kinsinger, met in Denver, December 11, to count ballots for 1981 officers. Elected officers are:

\section{President-Elect (1981) John Bohning \\ Directors (1981-83) Don Johnson \\ Alastair McLean}

Proposed bylaws were approved.

Directors Chuck Jarecki and William Laycock will leave the Board in February, 1981.

The following members of the Colorado and Wyoming Sections served as ballot counters under the supervision of the Elections Committee: Don Smith, Hayden Ronnsaville, Bob Buttery, Bob Newland, Lee Carr, Gordon Bentley, Ronnie Clark, Bob Hyde, Bill Krueger, Dave Kathman, Bob Wagner, Royal Hall, Herb Fisser, John Baker, Terry Foppe, Tom Eaman, Dan Merkel, Ed Dennis, Rick Harver, and John Clark.

Ballots and tally sheets are retained in the Denver office for one year for review. A total of 1,805 ballots were cast, or approximately $33 \%$ of the voting membership. 